\title{
Üniversite Okul Takımlarında Yer Alan Bireysel ve Takım Sporu Yapan Öğrencilerin Öfke Düzeylerinin Farklı Değişkenlere Göre İncelenmesi
}

\author{
Ünal TÜRKCAPAR ${ }^{1}$ ve Yavuz YASUL ${ }^{2}$
}

\section{Öz}

$\mathrm{Bu}$ araştırmanın amacı, üniversite ögrencilerinin öfke düzeylerini farklı değişkenlere göre araştırmaktır. Araştırmada betimsel nitelikli tarama modeli kullanıldı. Bu araştırma Kırgızistan Türkiye Manas üniversitesi bünyesinde farklı spor branşlarına sahip üniversite öğrencileri ile sürdürüldü. Çalışmaya 89 erkek 51 kadın katıldı ve gönüllü katılım kriteri esas alındı. Araştırmanın verileri araştırmacı tarafından hazırlanan kişisel bilgi formu ve sürekli öfke ve öfke tarzlarının belirlenmesi için sürekli Öfke-Öfke Tarz Ölçeği (SÖ-ÖTÖ) kullanıldı. Elde edilen veriler bilgisayar ortamında SPSS 21.0 istatistik programı aracılloğyla değerlendirildi. Normallik analizleri yapılarak ikili grup karşılaştırmaları için independent sample t testi üç ve daha fazla grup karşılaştırmaları için One Way Anova testi kullanıldı. Gruplar arasındaki karşılaştırmalarda ise LSD ve scheffe testleri kullanıldı. Çalışmanın sonucunda üniversite öğrencilerinin sürekli öfke - öfke tarz ölçeği alt boyutları ile cinsiyet, aktif spor yılı ve spor düzeyleri arasında anlamlı bir fark olmadığ1 görüldü ancak öğrencilerin sahip oldukları branş ve yaş değişkeni arasında sürekli öfke ve öfke dış alt boyutunun etkilendiği tespit edildi. Bu çalışmada tercih edilen spor branş1 ve yaş faktörü öğrencilerde öfke düzeylerinin belirlenmesi ve öğrencilerin öfkelerini kolay bir şekilde ifade edebilme yetenekleri üzerinde etkili olabileceği sonucuna varılmıştır.

Anabtar Kelimeler: Öfke, Spor Düzeyi, Spor Branşı, Üniversite

Analysis of Individual and Team Sports Students in University School Teams According to Different Variables

\begin{abstract}
The purpose of this study is to investigate university students anger levels acording to different variables. The descriptive survey model was used in the study this research was carried out within Kyrgyzstan Turkey Manas University college students with different sport their owners. 89 men and 51 women participated in the study and voluntary participation criteria were taken as basis. The data of the study were used in the personal information form prepared by the researcher and the constant anger- anger style scale (CA-ASS) to determine the trait anger and anger styles. The data obtained were evaluated in computer enviroment using the SPSS 21.0 statistics program. By conducting normality analyzes, independent sample $t$ test for pairwise group comprisons, One Way Anova test was used for comparisons of three or more groups. LSD and scheffe tests were used for comparisons between groups. As a result of the study, it was found that there was no significant difference between the sub-dimensions of the constant anger-anger style scale and gender and sports levels of the university students, but it was found that the external sub-dimension of constant anger and anger was affected among the branches of the students. In this study, it was concluded that some sports branches may have an effect on students abilities in determining their anger levels and expressing their anger easily.
\end{abstract}

Key Words: Anger, Sport Level, Sport Branch, University

\section{Atıf İçin / Please Cite As:}

Türkçapar, Ü., Yasul, Y. (2021). Üniversite Okul Takımlarında Yer Alan Bireysel ve Takım Sporu Yapan Öğrencilerin Öfke Düzeylerinin Farklı Değisskenlere Göre İncelenmesi. Manas Sosyal Araștırmalar Dergisi, 10(3), 1923-1931.

Geliş Tarihi / Received Date: 05.03.2021

Kabul Tarihi / Accepted Date: 27.04.2021

\footnotetext{
${ }^{1}$ Doç. Dr. - Kırgızistan Türk Manas Üniversitesi Beden Eğitimi ve Spor Yüksekokulu, Kırgızistan Kahramanmaraş Sütçü İmam Üniversitesi Beden Eğitimi ve Spor Yüksekokulu, turkcaparunal@hotmail.com

(iD ORCID: 0000-0002-4205-6446

2 Öğr. Gör. - Ondokuz Mayıs Üniversitesi Bafra Meslek Yüksekokulu, Samsun, Türkiye.

yavuzyasul@gmail.com/yavuz.yasul@omü.edu.tr

iD ORCID: 0000-0002-9458-1664
} 


\section{Giriş}

Öfke kimi zaman kısa süreli orta şiddette kişiye sonuçları açısından faydalı; kimi zaman ise daha uzun süreli, şiddetli ve yıkıcı sonuçları olabilmektedir. Sonuçları itibariyle genellikle hem birey hem de toplum açısından olumsuz bir duygu olarak kabul edilmektedir (Balkaya ve Şahin, 2003 s. 192-202). Öfke bir hedefe karşı hissedilen bilişsel ve fizyolojik tepkiler, hayal kırıklığı, şiddet ve kızgınlık durumlarını içerisinde barındıran engellenme durumlarında ortaya çıkan sonuçları itibariyle genellikle olumsuz olan iyi yönetildiğinde olumlu sonuçları olan bir kavram olarak tanımlanabilir (Berkowitz vd., 2004, s. 107-130).

Öfke duygusal, bilişsel, fizyolojik ve davranışsal öğeleri olan çok boyutlu bir kavram olarak ele alınmaktadır. Öfkenin duygusal boyutu, öfkeye sebep olan durumlara karşı duygusal tepkilerin gücü ile ilişkilidir. Bilişsel boyut; bireyin yaşadığı çevreye yönelik sahip olduğu olumsuz şemalarla ilişkiliykken; davranışsal boyut, öfkenin ifadesinde kullanılan olumlu ya da olumsuz başa çıkma mekanizmalarını içermektedir (Boman, 2003, s. 71-77).

Öfke, her bireyin farklı şekillerde yaşayabildiği bir duygu durumu olarak ifade edilmektedir (Kesen vd., 2007, s. 353-364). Bireyler, duygularına göre nasıl davranıp davranmayacaklarına kendileri karar vermektedir. Öfkenin tüm olumsuz sonuçlarına rağmen aslında kişiyi koruyucu, uyarıcı veya harekete geçirici işlevleri bulunmaktadır ve bu duygu yaşamın devamı için çok önemli bir yer tutmaktadır Öfke, son derece normal ve yaşamın sürdürülmesi için gerekli bir duygudur. Duygusal bir tepkidir, uyarıcı bir işarettir, kişiyi tehditlere karşı uyarır ve insanın kendisini korumasına olanak vermektedir. Öfke, kontrol edilebildiği sürece sağlıklıdır ve kişilerarası ilişkileri düzenlemede olumlu bir etkisi olabilir. Öfke, kontrol edilmediğinde kişinin kendisi ve çevresi için yıkıcı ve son derece tahrip edici bir hal almaktadır (Soykan, 2003, s. 19-27). Öfke duygusu zaman zaman ergenlerde ve yetişkinlerde çeşitli psikolojik problemlerle ilişkili olabilmektedir.

Öfke ve kızgınlık duygusu öncelikle öfkelenen kişiyi sonra çevresindeki kişileri etkiler. Kızgınlıkla ifade edilen her davranış yöneldiği kişiler için genellikle sıkıntı verici, tehdit edici, psikolojik ya da fiziksel olarak yaralayıcı olur. Arkadaş ve aile ilişkilerinin bambaşka bir boyuta ulaştığı ergenlik döneminde ise öfke iyi yönetilmezse çok yönlü bir yıkıma yol açabilir (Kalyoncu, 2014, s. 46-67). Öfke, bedensel bir sinyaldir. Biyolojik, psikolojik, kişilerarası ve kültürel birçok faktörden etkilenir. Bu yönüyle öfke duygusal bir davranış olarak görülebilmektedir (Leary vd., 2006, s. 111-132). Öfke sosyal değerlendirme açısından olumsuz duygu olarak değerlendirilebilmektedir. Küçük çocuklar genellikle öfkelendiklerinde ebeveyn veya öğretmen gibi bazı yetişkinler tarafından cezalandırılabilmektedir. Ancak her birey için öfke, kendisini ifade etmede öznel bir deneyimdir (Averil, 1983, s. 1145-1160).

Öfkenin anlaşılabilmesi ve kontrol altına alınabilmesi önemli bir beceridir. Bu becerinin çocukluk yıllarında ve ergenlik döneminin başlarında öğrenilmesi, bireyin sosyalleşmesi ve ergenlikten sonraki yaşamı için kritik bir öneme sahiptir (Duran ve Eldeleklioğlu, 2005, s. 267-280). Her insan bir hedefe karş1 çeşitli zamanlarda öfke duygusunu hissetmektedir. Rahatsız edici durumların olması, stresin etkisi, isteklerin elde edilememesi gibi olumsuz olarak değerlendirilebilecek durumlar bireyin öfke duygusu hissetmesine neden olmaktadır. Öfke duygusunun hissedildiği durumlarda genellikle hedefe karşı kaçınma davranışından ziyade öfkeyi yansıtmak amacıyla yaklaşma davranışı sergilenmektedir (Berkowitz ve Harmon-Jones, 2004, s. 107-130). Öfke ve düşmanlık düzeyleri yüksek insanlar her zaman saldırgan ve baskıcı davranışlar sergilemeyebilirler. Ancak bu insanların karşılaştıkları baskı ve engellemelere karşı tepki düzeyleri diğer insanlara göre aşırı olabilmektedir (Burger, 2006, s. 25-35). Öfke üç ana boyuta sahiptir. Ayrıca bu boyutlar birbirleriyle etkileşim halindedir ve birbirleriyle bağlantıllıdır. Bu boyutlar bilişsel, fizyolojik ve davranışsal boyut olarak sinıflandırlabilir (Robins ve Novaco, 1999, s. 325-337). Öfkenin bilişsel boyutu, bireyin beklentileri, inançlar gibi bilgi yapılarını ve belirli düzenlerde veya şemalarda düzenlenmiş olan yorumlama süreçlerini içerir. Öfkenin bilişsel boyutu, öfke konusunda olumlu ve olumsuz inanç türlerini de içerisinde barındırmaktadır (Boman, 2003, s. 71-77).

Bu çalışmanın amac1, Kırgızistan Türkiye Manas üniversitesinde öğrenim gören ve üniversite okul takımlarında yer alan bireylerin farklı değişkenlere göre öfke düzeylerini belirlemektir. 


\section{Yöntem}

\section{Araştırma Deseni}

Araştırma betimsel bir nitelikte olup, bireysel ve takım sporlar okul takımlarında yer alan bireylerin farklı değişkenlere göre öfke düzeylerini belirlemektir.

Bu çalışmada "tarama modeli” düşünülerek araştırmanın modeli oluşturulmuştur. Tarama modelleri, geçmişte veya şu anda var olan bir durumu olduğu şekilde tanımlamayı amaçlayan araştırma modelidir. Araştırmanın konusu olan olay, kişi ya da nesne, kendi koşulları içinde ve olduğu gibi aktarılmaya çalışılır. Bu koşulları herhangi bir şekilde değiştirme, etkileme amacı yoktur (Karasar, 2009).

\section{Çalışma Grubu}

Bu araştırmanın çalısma grubunu 2019-2020 eğitim öğretim yılında Kırgızistan Türkiye Manas üniversitesinde öğrenim gören ve üniversite okul takımlarında (futbol, fitness, teakwando, sambo, basketbol, judo, serbest güreş, grekoromen güreş, halter, boks ve voleybol) yer alan 89 erkek ile 51 bayan katılımcılardan oluşmaktadır.

\section{Veri Toplama Araçları}

Araştırmaya katılan üniversite öğrencilerinin demografik özelliklerini belirlemek amacıyla araştırmacı tarafından geliştirilen "Kişisel Bilgiler Formu" kullanılmışıı. Bu form; cinsiyet, yaş, spor branşınız, spor yapma yılınız ve spor düzeyiniz sorularından oluşmaktadır.

Araştırmada sürekli öfke ve öfke tarzlarının belirlenmesi için, orjinali 1983 yllında C. D. Spielberger tarafindan geliştirilmiş olan The State - Trait Anger Scale (STAS) ve Türkçe uyarlaması 1994 yllinda A. K. Özer tarafindan yapılmış Sürekli Öfke - Öfke Tarz Ölçeği (SÖ-Ö́TÖ) kullanılmıştır. Ergen ve yetişkinlerde öfke ve öfke tarzlarının belirlenmesi amacı ile kullanılan ölçek toplam 34 maddeden ve 4 alt boyuttan oluşmaktadır. Ölçeğin alt boyutları; Sürekli Öfke (10 madde), Öfke İç (8 madde), Öfke Dış (8 madde) ve Öfke kontrol (8 madde) olarak geçmektedir.

Araştırmada kullanılan Sürekli Öfke- Öfke Tarz Ölçeğinin alt ölçekleri ve bu ölçeklerin kapsadığ1 maddeler. Öfke İfade tarzları Özelliğin Ölçüldüğü Sorular;

Sürekli Öfke alt ölçeği 1, 2, 3, 4, 5, 6, 7, 8, 9, 10

Öfke İç alt ölçeği puanı 13, 15, 16, 20, 23, 26, 27, 31

Öfke Dış alt ölçeği puanı 12, 17, 19, 22, 24, 29, 32, 33

Öfke Kontrol alt ölçeğinin puanları 11, 14, 18, 21, 25, 28, 30, 34

Sürekli Öfke- Öfke Tarz Ölçeğinin alt ölçekleri ve bu ölçeklerin açıklamaları:

Sürekli Öfke; öfke düzeyinin yüksek olduğunu,

Öfke İç; öfkenin bastırılmış olduğunu,

Öfke Dış; öfkenin kolayca ifade ediliyor olduğunu,

Öfke Kontrol; öfkenin kontrol edilebildiğini gösterir.

\section{Verilerin Analizi}

Veriler Statistical Package for the Social Sciences (SPSS) 21,0 programı aracillğı ile analiz edildi. Verileri analizlerinde başlangıçta tanımlayıcı bilgiler (sayı, yüzde, ortalama, standart sapma) değerlendirildi. Çalışmada öfke- öfke tarz ölçeğinin alt ölçekleri ile araştırmacı tarafindan oluşturulan demografik değişkenlerin puanlarında normal bir dağılım olup olmadığını belirlemek için Kolmogorov Smirnov testi uygulandı. Bu test sonucunda verilerimizin normal dağıldı gözlemlendi. Bu yüzden ikili karşılaştırmalar için İndependent Sample T testi, üç ve daha fazla grup karşılaştırmaları için One Way Anova, LSD, Scheffe testleri kullanılmıştır. İstatistiksel anlamlılık düzeyi $\mathrm{p}<0.05$ olarak kabul edilmiştir. 


\section{Bulgular}

Tablo 1. Katılımclarn Sürekli Öfke-Öfke Tarz Ölçeğinden Aldlklar Puanlarn Cinsiyet Değğskeenine Göre Karşılașturlması Amaccyla Yapulan Analiz Sonuçlar

\begin{tabular}{|c|c|c|c|c|c|c|}
\hline SÖ-ÖTÖAB*** & Cinsiyet & $\mathbf{N}$ & Ortalama & SS & $t^{*}$ & $\mathrm{p}$ \\
\hline \multirow{2}{*}{ Sürekli Öfke } & Kadin & 51 & 20.54 & 4.84 & \multirow{2}{*}{-.489} & \multirow{2}{*}{0.62} \\
\hline & Erkek & 89 & 21.01 & 5.65 & & \\
\hline \multirow{2}{*}{ Öfke İç } & Kadin & 51 & 15.49 & 3.92 & \multirow{2}{*}{-1.536} & \multirow{2}{*}{0.12} \\
\hline & Erkek & 89 & 16.50 & 3.67 & & \\
\hline \multirow{2}{*}{ Öfke Dış } & Kadın & 51 & 16.37 & 3.35 & \multirow{2}{*}{-1.464} & \multirow{2}{*}{0.14} \\
\hline & Erkek & 89 & 17.41 & 4.40 & & \\
\hline \multirow{2}{*}{ Öfke Kontrol } & Kadin & 51 & 20.37 & 5.64 & \multirow{2}{*}{-1.677} & \multirow{2}{*}{0.09} \\
\hline & Erkek & 89 & 21.86 & 4.70 & & \\
\hline
\end{tabular}

*p>0.05; Independent sample t test, **Sürekli Öfke - Öfke Tarz Ölçeği Alt Boyutları

Tablo incelendiğinde sürekli öfke-öfke tarzı ölçeğini alt boyutları ile cinsiyet değişkeni arasında anlamlı bir fark yoktur ( $p>0.05$ ). Yani öfke düzeyi, öfkenin bastırılması, öfkenin kolayca ifade edilebilmesi ve öfkenin kontrol altında tutulmasında süreçlerinde bireyin sahip olduğu cinsiyet faktörü önemli değildir.

Tablo 2. Kathlimcularm Sürekli Öfke-Öfke Tarz Ölçeğinden Aldıklar Puanlarn Yaş Değģ̧̆kenine Göre Karşzlasterilması Amacyla Yapilan Analiz Sonuclar

\begin{tabular}{|c|c|c|c|c|c|c|c|}
\hline SÖ-ÖTÖAB** & Yaş & $\overline{\mathbf{N}}$ & $\overline{\text { Ortalama }}$ & SS & $\bar{F}$ & $\bar{p}$ & Grup Fark \\
\hline \multirow{5}{*}{ Öfke İç } & 18 & 25 & 15.52 & 3.48 & \multirow{5}{*}{1.067} & \multirow{5}{*}{0.37} & \\
\hline & 19 & 19 & 15.00 & 3.95 & & & \\
\hline & 20 & 34 & 16.02 & 3.76 & & & \\
\hline & 21 & 26 & 16.76 & 4.58 & & & \\
\hline & $22+$ & 36 & 16.80 & 3.19 & & & \\
\hline \multirow{5}{*}{ Öfke D1ş } & 18 & 25 & 15.36 & 2.75 & \multirow{5}{*}{2.719} & \multirow{5}{*}{$0.03^{*}$} & \multirow{5}{*}{$18,19<21,22$} \\
\hline & 19 & 19 & 15.78 & 3.32 & & & \\
\hline & 20 & 34 & 17.00 & 3.88 & & & \\
\hline & 21 & 26 & 18.19 & 4.34 & & & \\
\hline & $22+$ & 36 & 18.05 & 4.73 & & & \\
\hline \multirow{5}{*}{ Öfke Kontrol } & 18 & 25 & 21.20 & 5.25 & \multirow{5}{*}{0.341} & \multirow{5}{*}{0.85} & \\
\hline & 19 & 19 & 22.31 & 4.69 & & & \\
\hline & 20 & 34 & 20.64 & 4.98 & & & \\
\hline & 21 & 26 & 21.30 & 5.25 & & & \\
\hline & $22+$ & 36 & 21.52 & 5.37 & & & \\
\hline \multirow{5}{*}{ Sürekli Öfke } & 18 & 25 & 19.60 & 3.87 & \multirow{5}{*}{1.393} & \multirow{5}{*}{0.24} & \\
\hline & 19 & 19 & 19.21 & 4.64 & & & \\
\hline & 20 & 34 & 20.71 & 5.73 & & & \\
\hline & 21 & 26 & 22.15 & 6.59 & & & \\
\hline & $22+$ & 36 & 21,66 & 5.12 & & & \\
\hline
\end{tabular}

Tablo incelendiğinde sürekli öfke-öfke tarzı ölçeği boyutları ile yaş değişkeni arasında anlamlı bir fark vardır $(\mathrm{F}=2.71, \mathrm{p}<0.05)$. Bu fark öfke dış alt boyutu ile yaş değişkeni arasındadır. Yani 20 yaşında olan bireylerin diğer yaş grupları ile anlamlı bir fark yokken, 18,19 ile 20,21 yaş grupları arasında anlamlı bir fark vardır. Dolayısıyla 20 ve 21 yaşında olan bireyler 18 ve 19 yaşında olan bireylere göre öfkelerini daha kolay dışa vurduklarını söyleyebiliriz. 


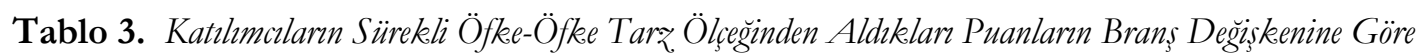
Karşılastorilması Amacyla Yapilan Analiz. Sonuclar

\begin{tabular}{|c|c|c|c|c|c|c|c|}
\hline SÖ-ÖTÖAB** & Branş & $\mathbf{N}$ & Ortalama & SS & $F$ & $\mathrm{p}$ & Grup Fark \\
\hline \multirow{9}{*}{ Sürekli Öfke } & Fitness $^{1}$ & 15 & 19.86 & 5.06 & \multirow{9}{*}{2.710} & \multirow{9}{*}{$0.09 *$} & \multirow{9}{*}{$\begin{array}{c}2>1,5 \\
8<2,3,5,7,9\end{array}$} \\
\hline & Futbol $^{2}$ & 15 & 24.13 & 3.71 & & & \\
\hline & $\mathrm{Sambo}^{3}$ & 15 & 21.60 & 3.64 & & & \\
\hline & Basketbol ${ }^{4}$ & 15 & 21.26 & 6.48 & & & \\
\hline & Judo $^{5}$ & 30 & 20.90 & 5.64 & & & \\
\hline & Ser.Gures ${ }^{6}$ & 15 & 17.66 & 5.23 & & & \\
\hline & Greko Roman ${ }^{7}$ & 10 & 22.50 & 6.15 & & & \\
\hline & Boks $^{8}$ & 15 & 17.73 & 5.13 & & & \\
\hline & Voleybol $^{9}$ & 10 & 23.20 & 3.22 & & & \\
\hline \multirow{9}{*}{ Öfke İç } & Fitness $^{1}$ & 15 & 15.93 & 3.32 & \multirow{9}{*}{0.869} & \multirow{9}{*}{0.54} & \\
\hline & Futbol $^{2}$ & 15 & 16.40 & 3.52 & & & \\
\hline & $\mathrm{Sambo}^{3}$ & 15 & 16.86 & 3.29 & & & \\
\hline & Basketbol $^{4}$ & 15 & 15.40 & 3.29 & & & \\
\hline & Judo $^{5}$ & 30 & 15.10 & 3.87 & & & \\
\hline & Ser.Gures ${ }^{6}$ & 15 & 14.40 & 2.97 & & & \\
\hline & Greko Roman ${ }^{7}$ & 10 & 17.00 & 4.85 & & & \\
\hline & Boks $^{8}$ & 15 & 15.53 & 4.82 & & & \\
\hline & Voleybol $^{9}$ & 10 & 16.00 & 4.21 & & & \\
\hline \multirow{9}{*}{ Öfke Diş } & Fitness $^{1}$ & 15 & 16.86 & 4.68 & \multirow{9}{*}{2.054} & \multirow{9}{*}{$0.04 *$} & \multirow{9}{*}{$\begin{array}{c}8<2,3,7,9 \\
6<2,5,7\end{array}$} \\
\hline & Futbol $^{2}$ & 15 & 18.60 & 2.69 & & & \\
\hline & $\mathrm{Sambo}^{3}$ & 15 & 17.33 & 3.49 & & & \\
\hline & Basketbol $^{4}$ & 15 & 17.13 & 3.70 & & & \\
\hline & Judo $^{5}$ & 30 & 17.70 & 4.54 & & & \\
\hline & Ser.Gures ${ }^{6}$ & 15 & 15.00 & 3.27 & & & \\
\hline & Greko Roman ${ }^{7}$ & 10 & 18.70 & 4.87 & & & \\
\hline & Boks $^{8}$ & 15 & 14.33 & 4.20 & & & \\
\hline & Voleybol $^{9}$ & 10 & 17.80 & 2.74 & & & \\
\hline \multirow{9}{*}{ Öfke Kontrol } & Fitness $^{1}$ & 15 & 22.73 & 4.87 & \multirow{9}{*}{1.786} & \multirow{9}{*}{0.08} & \\
\hline & Futbol $^{2}$ & 15 & 21.20 & 3.36 & & & \\
\hline & $\mathrm{Sambo}^{3}$ & 15 & 22.46 & 5.08 & & & \\
\hline & Basketbol $^{4}$ & 15 & 17.86 & 5.28 & & & \\
\hline & $\mathrm{Judo}^{5}$ & 30 & 22.23 & 4.52 & & & \\
\hline & Ser.Gures ${ }^{6}$ & 15 & 22.00 & 5.11 & & & \\
\hline & Greko Roman ${ }^{7}$ & 10 & 22.80 & 4.13 & & & \\
\hline & Boks $^{8}$ & 15 & 20.53 & 7.60 & & & \\
\hline & Voleybol $^{9}$ & 10 & 18.80 & 3.19 & & & \\
\hline
\end{tabular}

Tablo incelendiğinde sürekli öfke-öfke tarzı ölçeği boyutları ile branş değişkeni arasında anlamlı bir fark vardır $(\mathrm{F}=2.71,2.05, \mathrm{p}<0.05)$. Bu fark sürekli öfke, öfke diş alt boyutları ile branş değişkeni arasındadır. Sürekli öfke alt boyutuna baktı̆ıımıda futbol branşındaki sporcular ile fitness ve judo branşındaki sporculara arasında anlamlı bir farkın olduğunu görmekteyiz. Yani futbol branşındaki sporcuların fitness ve judo branşındaki sporculara göre öfke düzeyleri daha yüksek olduğu ortaya çıkmışır. Sürekli öfke alt boyutundaki diğer bir anlamlı fark ise boks ile futbol, sambo, judo ve voleybol arasındadır. Yani boks branşındaki sporcularnn diğer dört branştaki sporculara göre öfke düzeyleri en düşük seviyede olduğunu görmekteyiz.

Öfke dış alt boyutunda ise boks branşındaki sporcular futbol, sambo, greko roman ve voleybol branşındaki sporculara göre öfkelerini ifade etme konusunda zorlandıklarını görmekteyiz. Ayrıca serbest güreş ile uğraşan sporcuların futbol, judo ve greko roman branşındaki sporculara göre öfkelerini ifade etme konusunda zorlandıklarını da ifade edebiliriz. Sonra olarak bu çalışmada diğer iki alt boyut ile spor branşları arasında anlamı bir fark ortaya çıkmamıştır. 
Tablo 4. Kathlmollarn Sürekli Öfke-Öfkee Tarz Ölçeg̈inden Aldıklar Puanlarn Aktif Spor Yulı Değģskeenine Göre Karşılassturlması Amaciyla Yapılan Analiz Sonuclar

\begin{tabular}{ccccccc}
\hline SÖ-ÖTÖAB $* *$ & Aktif Spor Y1l1 & N & Ortalama & SS & F* & P \\
\hline \multirow{3}{*}{ Sürekli Öfke } & 1 & 35 & 19.40 & 5.34 & & \\
& 2 & 57 & 21.22 & 5.82 & 1.727 & 0.18 \\
\hline \multirow{2}{*}{ Öfke İç } & $3+$ & 48 & 21.43 & 4.67 & & 0.49 \\
& 1 & 35 & 16.00 & 3.53 & & \\
\hline \multirow{2}{*}{ Öfke Diş } & 2 & 57 & 16.57 & 4.32 & 0.717 & 0.21 \\
& $3+$ & 48 & 15.70 & 3.24 & & \\
\hline \multirow{2}{*}{ Öfke Kontrol } & 1 & 35 & 16.25 & 4.03 & & \\
& 2 & 57 & 17.71 & 3.87 & & 0.68 \\
\hline
\end{tabular}

*p>0.05; One Way Anova, **Sürekli Öfke - Öfke Tarz Ölçeği Alt Boyutları

Tablo incelendiğinde sürekli öfke-öfke tarzı ölçeğini alt boyutları ile aktif spor yllı değişkeni arasında anlamlı bir fark yoktur ( $>00.005$ ). Yani uzun süreli veya kısa süreli bir branş sporu ile uğraşmanız öfke düzeyiniz, öfkenizin bastrrlması, öfkenizin kolayca ifade edilmesinde ve öfkenin kontrol edilmesinde önemli değildir.

Tablo 5. Katıllmcılarn Sürekli Öfke-Öfke Tarz Ölceğinden Aldıklar Puanlarn Spor Düzeyi Değğskenine Göre Karşılaștirlması Amacylla Yapılan Analiz. Sonuçarı

\begin{tabular}{|c|c|c|c|c|c|c|}
\hline SÖ-ÖTÖAB** & Spor Düzeyi & $\overline{\mathbf{N}}$ & Ortalama & $\overline{\text { SS }}$ & $\bar{F}$ & $\mathbf{P}$ \\
\hline \multirow{2}{*}{ Sürekli Öfke } & Amatör Sporcu & 84 & 20.50 & 5.51 & \multirow{2}{*}{0.858} & \multirow{2}{*}{0.35} \\
\hline & Profesyonel-Milli Sporcu & 56 & 21.35 & 5.12 & & \\
\hline \multirow{2}{*}{ Öfke İç } & Amatör Sporcu & 84 & 16.27 & 4.04 & \multirow{2}{*}{0.278} & \multirow{2}{*}{0.59} \\
\hline & Profesyonel-Milli Sporcu & 56 & 15.92 & 3.37 & & \\
\hline \multirow{2}{*}{ Öfke Diş } & Amatör Sporcu & 84 & 16.95 & 4.07 & \multirow{2}{*}{0.087} & \multirow{2}{*}{0.76} \\
\hline & Profesyonel-Milli Sporcu & 56 & 17.16 & 4.10 & & \\
\hline \multirow{2}{*}{ Öfke Kontrol } & Amatör Sporcu & 84 & 21.72 & 4.87 & \multirow{2}{*}{1.326} & \multirow{2}{*}{0.25} \\
\hline & Profesyonel-Milli Sporcu & 56 & 20.71 & 5.41 & & \\
\hline
\end{tabular}

*p>0.05; One Way Anova, **Sürekli Öfke - Öfke Tarz Ölçeği Alt Boyutları

Tablo incelendiğinde sürekli öfke-öfke tarzı ölçeğini alt boyutları ile spor düzeyi değişkeni arasında anlamlı bir fark yoktur ( $\mathrm{p}>0.05$ ). Yani amatör, profesyonel veya milli sporcu olmanız öfke düzeyinizi, öfkenizin bastırlmasını, öfkenizi kolayca ifade edilmesi ve öfkenizin kontrol edilmesi üzerinde önemli bir etkisi yoktur.

\section{Tartışma, Sonuç ve Öneriler}

Yapılan araştırma değerlendirilmeye alınan değişkenlere göre literatür bilgileri ışı̆̆ında değerlendirilmeye çalışılmışır.

Araştırma grubunun sürekli öfke-öfke tarzı ölçeğini alt boyutları ile cinsiyet değişkeni arasında anlamlı bir fark olmadığı görülmüştür. Shokoufeh (2018) ve Yavuz (2015) çalışmalarında saldırganlık ve öfke toplam puanlarının cinsiyete göre anlamlı farklılık göstermediği bulgularını elde etmiştir. Aynı șekilde Araz (2017) ve İnallı (2019) yapmış olduğu çalışmalarda, cinsiyet ile öfke ölçeğinin tüm alt boyutları arasında herhangi anlamlı bir farklılık ortaya konulmamıştır. Ancak, Baykan (2018) ve Bozkurt (2017) çalışmalarında öfke puanlarının cinsiyete göre anlamlı farklılık gösterdiği bulgularını elde etmişlerdir. Literatürde öfke cinsiyete göre farklılaştı̆̆ını gösteren çalışmalar olduğu gibi bu çalışmada olduğu gibi öfkenin farklılaşmadığını gösteren çalışmalar da bulunmaktadır. Bu durum öfkenin cinsiyete göre farklılaştığını söylemek yerine bireyin kişilik özelikleri, psikolojik durumu, sosyal koşulları gibi değişkenlerle açıklanabileceğini göstermektedir.

Araştırma grubunun sürekli öfke-öfke tarzı ölçeği boyutları ile yaş değişkeni arasında anlamlı bir fark olduğu sonucuna ulaşılmıştır. Bu fark öfke dış alt boyutu ile yaş değişkeni arasındadır. Yani 20 yaşında olan bireylerin diğer yaş gruplanı ile anlamlı bir fark yokken, 18,19 ile 20,21 yaş grupları arasında anlamlı bir fark vardır. Baykan (2018)'ın yapmış olduğu çalışmada yaş arttıkça sürekli öfke, içe yönelik öfke ve dışa yönelik 
öfke düzeylerinde anlamlı farkl1lıklar olduğu ortaya çıkmıştır. Ancak öfke kontrol alt boyutunda herhangi anlamlı bir farklılığa rastlanmamıştır. Bu durum çalışmamızla paralellik göstermektedir. Fakat İbrahim'in (2018) yaptı̆̆1 farklı bir çalışmada çalışmaya katılan katılımcıların yaşları açısından öfke ölçeği alt boyutlarında herhangi anlamlı bir farklıllğa rastlanmamıştır.

Araştırma grubunun sürekli öfke-öfke tarzı ölçeği boyutları ile branş değişkeni arasında anlamlı bir fark olduğu sonucuna ulaşılmıştır. Bu fark sürekli öfke, öfke dış alt boyutları ile branş değişkeni arasındadır. Sürekli öfke alt boyutuna baktı̆̆ımızda futbol branşındaki sporcular ile fitness ve judo branşındaki sporculara arasında anlamlı bir farkın olduğunu görmekteyiz. Yani futbol branşındaki sporcuların fitness ve judo branşındaki sporculara göre öfke düzeyleri daha yüksek olduğu ortaya çıkmıştır. Futbolcuların genel yapıları olarak ve yaptıkları iş olarak statüleri ne olursa olsun benzer tutumlar sergiledikleri söylenebilir. Bu açıdan bakıldığında gerek profesyonel ligde olsun gerekse amatör ligde olsun verdikleri çabanın başarıya yönelik olması, beklentinin kazanmaya dönük olması gibi motive edici etmenlerden dolayı benzer davranış sergilemeleri ve öfkelerini benzer düzeyde kontrol edebilmeleri yaptıkları işin çok farklılık göstermemesi ve benzer süreçler yaşamaları ile açıklanabilir. Kızmaz'in (2004) aktardığına göre James ve Johnson (1983), bireysel spor yapan sporcuların daha gergin ve öfkeli olduğunu tepkisel özellik gösterdiklerini belirtmişlerdir. Robazza, Bertolli ve Bortoli (2006), gerek takım gerekse bireysel sporda olsun tüm sporcuların öfke düzeylerini tetikleyen en önemli unsurun rekabet olgusu olduğunu vurgulaması, öfkenin ne kadar karmaşık süreçler içerdiği ve tek bir boyutla açıklanamayacağ1 şeklinde yorumlanabilir. Araştırmacılara göre takım sporları yapan sporcuların kendi özellikleri ile birlikte takım arkadaşlarının bireysel farklılıklarının da dikkate aldıkları, çalışıırıcıların ve yöneticilerin de bir bütün oluşturarak sporcular üzerinde bir etki yaptığı ve daha çok bireysel değil takım içinde genel belirtilerin olması gerektiği bilincini geliştirme ve sorumluluk yükleme ile açılanabilir. Demir vd. (2017, s. 408-414) sporcuların öfke belirtme biçimlerini incelediği araştırmada bireysel spor yapanların dişa yönelik öfkelerinin daha fazla olduğunu, bireysel sporcularının takım sporu ile uğraşanlara göre daha saldırgan davranış içinde olduklarını tespit etmişlerdir. Takım sporu ve bireysel spor yapan bireylerin saldırganlık seviyelerini saldırganlığı etkileyen bazı etkenler yönünden 120 takım sporu ve 120 bireysel spor yapan bir örneklem grubuyla değerlendiren Tutkun ve arkadaşları (2010, s. 23-29) öfke kontrolüne sahip sporcuların daha çok takım sporlarında olduğunu tespit etmişlerdir. Ancak; İnallı (2019)'ın yüzme, triatlon, yelken gibi bireysel sporlarla ilgilenen sporcularla su alt1 ragbisi ve sutopu gibi takım sporlarıly ilgilenen sporcuların öfke düzeylerini karşılaştırdığı çalışmasında herhangi anlamlı bir fark tespit edememiştir.

Araştırma grubunun sürekli öfke-öfke tarzı ölçeğini alt boyutları ile aktif spor yllı değişkeni arasında anlamlı bir fark olmadığ1 sonucuna ulaşılmıştır. Yani uzun süreli veya kısa süreli bir branş sporu ile uğraşmanız öfke düzeyiniz, öfkenizin bastırılması, öfkenizin kolayca ifade edilmesinde ve öfkenin kontrol edilmesinde önemli değildir. Yıldız'n (2008) profesyonel, paf ve amatör liglerde oynayan 300 futbolcu üzerinde yaptığ1 çalışmasında, yıl değişkeni açısından sürekli öfke ve öfke tarzlarında anlamlı bir farka rastlanmamıştır. Kızmaz (2004), yaptığı araştırmasında spor yapma yllı arttıkça sporcunun, sosyal olgunluk yönü, sosyal beceri yönü, başkalarını seven ve sevilen, davranışları kabul gören, toplum değerlerine saygıll, başkalarını haklarını tanıyan, kendine güven duyan, cesaretli olma, başkalarına zarar vermekten kaçınma, aile ve arkadaşlarıyla dostça yaşama gibi özelliklerin geliştiğini belirtmiştir. Certel ve Bahadır’ın (2012, s. 157-164) farklı kulüplerde takım sporu yapan sporcuların benlik saygısı ve öfke tarzları arasındaki ilişkiyi incelediği çalısmanın bulgularına göre 1-9 yıl arası spor yapan sporcuların 10-14 yıl arası spor yapan sporculara göre dışa yönelik öfke biçimlerini daha fazla kullandıklanı görülmektedir. İmamoğlu Kaya (2019) kadın futbolcularla yapmış olduğu çalışmada, kadın futbol takımı oyuncularından 1-4 yıl spor deneyimine sahip olanların öfke kontrolü puan ortalamaları 5-9 yil spor deneyimine sahip olanlardan anlamlı bir şekilde daha yüksek bulunmuştur. İmamoğlu Kaya (2019) kadın futbolcularla yapmış olduğu çalışmada, takımların bulunmuş olduğu lig düzeylerine göre öfke ölçeği alt boyutlarını karşılaştırmıştır. Sürekli öfke, öfke dışa vurumu ve öfke kontrolü puan ortalamalarının istatistiksel olarak anlamlı bir farklılık içerdiği tespit edilmiştir. Buna göre birinci lig kadın futbol takımı oyuncularının ikinci lig kadın futbol takımı oyuncularına göre sürekli öfke ve dışa yönelik öfke puanları daha yüksekken; öfke kontrolü puanında ise birinci lig kadın futbol takımı oyuncularının puanı ikinci lig kadın futbol takımı oyuncularının puanından daha düşüktür. Buradan hareketle rekabet arttıkça öfke düzeyi artmaktadır. Okul takımlarındaki rekabet düzeyinin amatör takımlardaki rekabet düzeyinden fazla oluşunun bu sonuca etki ettiği düşünülmektedir.

Sporcuların gelişimleri ve psikolojik duygu durumları iyi saptanmalı ve ona göre uygun yaklaşım sergilenmelidir. Sporculara öfke ve öfke ifade tarzlarına dönük olarak gerekli eğitim ve bilgilendirme 
yapılmalıdır. Sporda öfkenin varlığını ve özellikle sportif müsabakalarda öfke kontrolünün önemini ortaya koyan nitel çalışmalarda yapılmalıdır.

\section{Etik Beyan}

"Üniversite okul takımlarnda yer alan bireysel ve takım sporu yapan ögrencilerin öfke düzeylerinin farki değğskenlere göre incelenmesi” başlıklı çalışmanın yazım sürecinde bilimsel, etik ve alıntı kurallarına uyulmuş; toplanan veriler üzerinde herhangi bir tahrifat yapılmamıştır. Bu çalışmanın bazı değişkenleri (cinsiyet, spor düzeyleri ve branşlar) IX. uluslararası Türk Halklarının Geleneksel Spor Oyunları sempozyumunda bildiri olarak sunulmuştur. Çalışmanın etik kurul kararı Selçuk Üniversitesi Spor Bilimleri Fakültesi girişimsel olmayan klinik araştırmalar etik kurulu 25.02.2021 tarih, 18. saylı karar ile alınmıştır.

\section{Kaynakça}

Araz, G. Y. (2017). Spor yapan bireylerin kaygu düzeyleri, saldrrganlke eğilimleri ve yaklasma-uzaklasma tepkilerinin incelenmesi (Yüksek Lisans Tezi). Trakya Üniversitesi Sağlık Bilimleri Enstitüsü, Edirne.

Averill, J. R. (1983). Studies on anger and aggression: implications for theories of emotion. American Psychologist, $38(11), 1145-1160$.

Balkaya, F. ve Şahin, N. H. (2003). Çok boyutlu öfke ölçeği. Türk Psikiyatri Dergisi, 14(3), 192-202.

Baykan, E. (2018). Y ve Z nesil taekwondocularn sürekli öfke düzeylerinin saptanması ve iliskili faktörlerin incelenmesi (Yüksek Lisans Tezi). Bozok Üniversitesi Sağllk Bilimleri Enstitüsü, Yozgat.

Berkowitz, L. ve Harmon-Jones, E. (2004). Toward an understanding of the determinants of anger. Emotion, 4(2), $107-130$.

Boman, P. (2003). Gender differences in school anger. International Education Journal, 4(2), 71-77.

Bostanc1, N., Albayrak, B., Bakoğlu, İ. ve Çoban, Ş. (2006). Üniversite öğrencilerinde çocukluk çağı travmalarının depresif belirtileri üzerine etkisi” New/Yeni Symposium Journal, 44(4), 189-25.

Bozkurt, B. (2017). Genc kategorisindeki bireysel ve takem sporcularmn öfke kontrollerinin değerlendirilmesi (Yüksek Lisans Tezi). Haliç Üniversitesi Sağlık Bilimleri Enstitüsü, İstanbul.

Burger, J. M. (2006). Kişilik (1. Baskı). İstanbul: Kaknüs Yayınları.

Certel Z, Bahadır Z. (2012). Takım sporu yapan sporcularda benlik saygısı ve sürekli öfke ve öfke ifade tarz ilişkisinin incelenmesi. Selçuk Üniversitesi Beden Eğitimi ve Spor Bilim Dergisi, 14(2), 157-164.

Demir, H., Sezan, T., Demirel, H., Yalçın, Y. G. ve Altın, M. (2017). Sporcuların öfke ifade tarzları. Mehmet Akif Ersoy Üniversitesi Sosyal Bilimler Enstitiusü Dergisi, 9(9), 408-414.

Duran, Ö. ve Eldeleklioğlu, J. (2005). Öfke kontrol programının 15 ve 18 yaş arası ergenler üzerindeki etkililiğinin araştırilması. Gazi Eğitim Fakültesi Dergisi, 25(3), 267-280.

Hamdan-Mansour, A. M., Dardas, L. A., Nawafleh, H. ve Abu-Asba, M. H. (2012). Psychosocial predictors of anger among university students. Children and Youth Services Review, 34, 474-479

İbrahim, İ. M. S. (2018). Irak ve Türkiye'de ögrenim gören üniversite ögrencilerinin öfke ifade tarzllar (Doktora Tezi). Selçuk Üniversitesi Sağllk Bilimleri Enstitüsü, Konya.

İmamoğlu Kaya, M. (2019). Kadin futbolcularda antrenmanm algilanan stres, sporda güdülenme, sürekli öflee ve öfke tarz? düreylerine etkisi (Yüksek Lisans Tezi). Hitit Üniversitesi Sağllk Bilimleri Enstitüsü, Çorum.

İnall, Ç. (2019). Su sporlaryla uğraşan sporcularn beş faktör kişsilik yapilar ve öflee ifade tarzlarn arasindaki ilişki (Yüksek Lisans Tezi). Manisa Celal Bayar Üniversitesi, Sağlık Bilimleri Enstitüsü, Manisa.

Kalyoncu, H. (2014). Aile içi şiddet ve şiddet ortaminda gocuklar (1. Baskı). İstanbul: Yediveren Yayınevi.

Karasar, N. (2009). Arastirmalarda rapor hazerlama. Ankara: Nobel Yayınevi.

Kaya, N. ve Solmaz, F. (2009). Bir üniversite hastanesinin kulak burun boğaz kliniğinde çalışan hemşirelerin öfke ve ifadesi. Türkiye Klinikleri Hemsirelike Bilimleri Dergisi, 1(2), 56-64.

Kesen, N. F., Deniz, M. E. ve Durmuşoğlu, N. (2007). Ergenlerde saldırganlık ve öfke düzeyleri arasındaki ilişki: yetiştirme yurtları üzerinde bir araştırma. Selçke Üniversitesi Sosyal Bilimler Enstitiusï Dergisi, 1(17), 353-364.

Leary, M. R., Twenge, J. M. ve Quinlivan, E. (2006). Interpersonal rejection as a determinant of anger and aggression. Personality and Social Psychology Review, 10(2), 111-132.

Özer, A. K. (1994). Sürekli öfke ve öfke ifade tarzı ölçeği ön çalışması. Türk Psikoloji Dergisi, 9, 26-35.

Robins, S. ve Novaco, R. W. (1999). Systems conceptualization and treatment of anger. Journal of Clinical Psychology, 55(3), 325-337.

Shokoufeh, S. (2018). Türkiye'de elit erkek, ve bayan güressciler ile spor yapmayan bireylerin zibinsel yetenek, liderlik, ve salderganllk. dürzylerinin incelenmesi (Doktora Tezi). Ondokuz Mayıs Üniversitesi Sağlık Bilimleri Enstitüsü, Samsun.

Soykan, Ç. (2003). Öfke ve öfke yönetimi. Krį Dergisi, 11(2), 19-27.

Tutkun, E. Güner, B. Ağaoğlu, A. ve Soslu, R. (2010). Takım sporları ve bireysel sporlar yapan sporcuların saldırganlık düzeylerinin değerlendirilmesi. Spor ve Performans Araştrmalar Dergisi, 1(1), $23-29$.

Yavuz, S. (2015). Farklı spor dallarındaki sporcu, seyirci ve yöneticilerin küresel vatandaşlık ve saldırganlık ilişkisi (Adana-Mersin ili örneği) (Yüksek Lisans Tezi). Dumlupınar Üniversitesi Sağlık Bilimleri Enstitüsü, Kütahya.

Yıldız M. (2008). Farkla liglerde yer alan futbolcularn kişilik, tipleri ile sürekli öfkee- öfke ifade tarzlarmm incelenmesi (Doktora Tezi). Ankara: Gazi Üniversitesi. 
Yöndem, Z. D. ve Bıçak, B. (2008). Öğretmen adaylarının öfke düzeyi ve öfke tarzları. Uluslararası Insan Bilimleri Dergisi, 5(2), 1-15.

\section{EXTENDED ABSTRACT}

The physiological dimension of anger includes high hormone levels and low stimulus thresholds for the activation of arousal. Anger; Physiological activation in cardiovascular, endocrine, limbic systems and tension in skeletal muscles constitute the physiological effects of anger (Robins and Novaco, 1999). In the case of anger, as in other emotional states, symptoms such as increase in blood circulation and increase in heart rate can be seen starting with adrenaline secretion, which is also expressed as "general arousal state" (Yöndem, \& Biçak, 2008). The behavioral dimension of anger includes various learned repertoires that express anger. It can be defined as the behaviors demonstrated by an individual who experiences a sense of anger, including avoidance of current behavior and aggression (Robins, \& Novaco, 1999). It refers to the positive or destructive coping mechanisms used in anger expression (Boman, 2003). Although anger is an extremely healthy emotion, anger that is not properly expressed can lead to destructive behavior. These behaviors can negatively affect the social life of the person. It can cause problems such as smoking, substance addiction, eating disorders and depression. Therefore, destructive anger should be controlled (Soykan, 2003; Özer, 1994). Regardless of the emergence of anger, it is actually an emotion that can be understood, controlled, accepted, and can work when effectively controlled, just like many other emotions (Soykan, 2003). Throughout daily life, people of all ages inevitably experience anger and it is a universal emotion. It is known that the level of anger experienced by the individual and the way this anger is expressed plays an important role in the psychological and physical health of the individual and his / her relationships with other people. In studies conducted with university students, it was found that students' anger levels were at an average level (Bostanc1 et al., 2006; Kaya \& Solmaz, 2009; Hamdan-Mansour et al., 2012). In cases where the individual ignores his anger and cannot control his anger in healthy ways, aggressive behavior occurs and can cause harm to both the individual and the individual's environment. In order for anger to be resolved before it turns into aggression and violent behavior, the individual must be aware of his anger, accept his anger, and control his anger expression (Soykan, 2003; Özer, 1994). The purpose of this study, studying in Kyrgyzstan Turkey Manas University and according to different variables to determine the anger level of individual schools in the university team. The research is descriptive and aims to determine the anger levels of individuals in individual and team sports school teams according to different variables. The working group of the 2019-2020 academic year studying at universities in Kyrgyzstan Turkey Manas University and located in the school team (football, fitness, taekwondo, sambo, basketball, judo, freestyle wrestling, Greco-Roman wrestling, weightlifting, boxing and volleyball) consists of 89 male and 51 female participants. The "Personal Information Form" developed by the researcher was used to determine the demographic characteristics of the university students participating in the study. This form; consists of gender, age, your sports branch, your sport year and your sports level. The State - Trait Anger Scale (STAS), which was originally developed by C. D. Spielberger in 1983, and the Trait Anger - Anger Style Scale (TA-ASS), adapted to Turkish by A. K. Özer in 1994, were used in the study to determine trait anger and anger styles. The scale, which is used to determine anger and anger styles in adolescents and adults, consists of 34 items and 4 sub-dimensions. The sub-dimensions of the scale; Continuous Anger (10 items), Anger In (8 items), Anger Out (8 items) and Anger control (8 items). The data were analyzed using the Statistical Package for the Social Sciences (SPSS) 21.0 program. In the data analysis, initially, descriptive information (number, percentage, mean, standard deviation) was evaluated. The Kolmogorov Smirnov test was used to determine whether there was a normal distribution in the scores of the subscales of the anger-anger style scale and the demographic variables created by the researcher. As a result of this test, it was observed that our data were distributed normally. Therefore, Independent Sample $\mathrm{T}$ test was used for paired comparisons and One Way Anova, LSD, Scheffe tests were used for comparisons of three or more groups. Statistical significance level was accepted as $\mathrm{p}<0.05$. In this study, it was concluded that some preferred sports branches might affect students' anger levels and their ability to express their anger easily. Therefore, the development and psychological mood of athletes should be determined well and appropriate approach should be taken accordingly. Necessary training and information should be provided to athletes regarding anger and anger expression styles. Qualitative studies that reveal the existence of anger in sports and the importance of anger control especially in sportive competitions should be conducted. 